\title{
Impact of Traffic Connectivity on Island Development
}

\section{Utjecaj prometne povezanosti na razvoj otoka}

\author{
Antonija Mišura \\ University of Split
Faculty of Maritime Studies \\ e-mail: amisura@pfst.hr \\ David Sopta \\ Jadrolinija \\ Rijeka \\ e-mail: david.sopta@jadrolinija.hr \\ Ana Perić Hadžić \\ University of Rijeka \\ Faculty of Maritime Studies \\ e-mail:ana@pfri.hr
}

Summary

Today the main problems of the islands are the poor demographic picture caused by depopulation, low birth rate, prevalence of the elderly population, and relatively low economic activities. In that reason, the paper presents the influence of the traffic connections between Croatian's islands and mainland on the demographic picture of the islands. The aim of this paper is to conduct systematic and scientifically research of influence various factors on the demographic picture of the islands in order to insure the sustainable development of the islands and the retention of the inhabitants on the islands. This paper analyzes the population of Croatian's islands according to the latest census and the category is correlated with the most prominent limiting factor of development, which is the traffic connection between islands and mainland. The research shows that the improvement of traffic connection and increased density of traffic network between islands and mainland does not have a direct impact on the number of island's population, but it has a positive impact on all economic and social activities, by creating the prerequisites for sustainable development of the islands and raising the quality of life on islands, as evidenced by the growth of the island's population on bridged islands and drop population in small islands and islands unrelated to bridges.

\section{Sažetak}

Danas su glavni problemi na otocima loša demografska slika uzrokovana depopulacijom, niske stope rođenih, pretežito starija populacija i relativno oskudne ekonomske aktivnosti. $U$ tom smislu članak predstavlja utjecaj prometnih povezanosti među hrvatskima otocima i kopnom te demografsku sliku otoka. Cilj je ovoga članka provesti sustavno iznanstveno istraživanje ujecaja različitih čimbenika na demografsku sliku otoka kako bismo osigurali održivi razvoj otoka i zadržali stanovnike na otocima. Ovaj članak analizira populaciju otokâ prema zadnjem popisu stanovništva i kategoriju povezanu s najistaknutijim ograničavajućim čimbenikom razvoja, to jest prometnu povezanost među otocima i kopnom. Istraživanje pokazuje da poboljšanje prometne povezanosti i povećana gustoća prometne mreže između otoka i kopna nema izravan utjecaj na razinu populacije na otoku, ali ima pozitivan utjecaj na sve ekonomske $i$ društvene aktivnosti, stvaranjem pretpostavki za održivi razvoj otoka i podizanje kvalitete života na otocima, kao što je evidentirano porastom populacije na otocima s mostom i padom populacije na malim otocima i otocima nepovezanih mostom.
DOI 10.17818/NM/2020/1.10

UDK 656:314.1(210.7)

Review / Pregledni rad

Paper accepted / Rukopis primljen: 26. 9. 2019.

\section{KEY WORDS}

island's population

transport connection between

islands and mainland

island's economy

sustainable development

\section{INTRODUCTION / Uvod}

Important natural resources for Croatia are the sea and the coast because in addition to making the area attractive for housing and vacation, they are directly connected with almost all economic activities. The sea has always enabled us to connect with the whole world and it does not only allow us to communicate with other countries, but across the coast through the sea, different cultures and economic systems are meeting.

Croatian coast is amongst the most indented ones in Europe and in the world given it has 1246 islands, islets and reefs [4] which give a number of advantages especially in the category of natural beauties, however, this advantage also greatly obliges. Isolation of islands often means inability to satisfy a number of needs of island's population due to the poor traffic connectivity, lack of medical and social care, lack of schools and kindergartens, entertainment content, difficult supply of goods and somewhere even the absence or poor electricity and water supply, etc. In order to prevent the shutdown of life on islands, all deficiencies should be reduced to the lowest possible level. An island is not only an isolated entity but also a part of island and island-coastal groups without which they cannot survive, so it is indispensable for its sustainability and development a better connection with all the groups.

According to the last census in 2011,2,92\% of total Croatia's population lives on islands [6]. Although in recent times more attention is being devoted to preservation and improvement of life on islands, islands and islands' population are facing many problems, one of which is the basic problem of depopulation that will transform many inhabited islands' towns into occasionally 
inhabited or even uninhabited towns. The goal is to preserve life on islands and to stimulate their future development, therefore, it is necessary to sanitise the situation, revive islands and proper use of island resources and to minimise all the shortcomings of life on islands.

The theme of this paper is a consideration of an extremely important factor for islands which is the connection with the mainland, and the influence of this factor on the demographic image of islands and the economic development. The systematic study of the connection between Croatian islands and the mainland and the effect of this factor on all aspects of the islands' development, basic assumptions were created that traffic connection between islands and the mainland has a decisive role in islands' economic development, and thus an indirect impact on the demographic image of islands.

The paper is structured as follows; after the introduction, Chapter 2 provides an overview of the present researches. Chapter 3 presents the importance of the island's traffic connection with the mainland. Chapter 4 analysis the island's population in the Republic of Croatia, while Chapter 5 analysis the island's economy. Chapter 6 presents conclusions, followed by a list of used literature (references).

\section{OVERVIEW OF THE PREVIOUS RESEARCH / Pregled prethodnoga istraživanja}

Islands and their development is a highly represented area of research. The island as a separate entity from the mainland faces many challenges to retain its population and achieve sustainable development. Baldacchino (2019) explores the impact of the physical separation of an island on its developmental fate and concludes that islands farther from the mainland have a more difficult development way, but bigger autonomy, which can be an advantage while islands closer to the mainland are often more influenced by land centers and politics which complicates their possible development [3]. Marinković (2016) emphasizes that a key element of optimal sustainable development of island space is the classification of islands according to socio-geographical determinants, that is, the development requires scientifically based identification, systematization and comprehensive analysis [4]. Magaš (1996) analysis the problem of island's depopulation, feeling of isolation and dependence on the land and finds a solution in attributing the island as one of the developmental center, which would be a requirement for improving the demographic picture of the island [5]. Scientific literature points out that the primary aim is the rational development of islands and implies economic development which would create the preconditions for retaining the inhabitants of the islands, and especially the attraction of the younger age group. If the islands have no population, they die out. Magaš (2011), on the example of Ist and Skarda, emphasizes the advantages of islands in their natural and geographical features as the most important resources that enable them economic development through agriculture, fishing, livestock breeding and a significantly growing segment of tourism which must be handled very carefully because of possibility of non-return devastation of the island's space [6]. In a very similar way, Zlatar (2010) addresses this issue on the example of the town of Povlja on the island of Brac [7]. In the past, fish processing factories have played a key role in the life of the island and the island's population. Unfortunately, over time many fish processing factories have closed, which has had a significant impact on the islands. Jovanovic et al. (2010) investigated this phenomenon and concluded that there was an unquestionable connection between the closure of fish processing factories and depopulation [8]. Yang et al. (2016) point out the transformation of the island due to the unstoppable development of tourism that has overcome all other island's activities which has the negative impact on the environment and ecology, so the paper is emphasizing the importance of reasonable long-term sustainable development [9]. This does mean that the development of the island's tourism is something negative, but reality and objectivity are a necessity. Vidučić (2007) concludes that if the sustainable development of the island's tourism realized by the character of the island, it would have a positive effect on the problem of depopulation and quality of life of the island's population [10]. Delibašić and Vidučić (2003) link directly tourism development and maritime transport what can reduce depopulation but with required investment in optimal vessels [11]. The traffic connection of the island to the mainland is one of the most important elements of the island's survival and development, but Mrvica et al. (2015) point the need to increase the functionality of ship connections the islands to the mainland so that good connection is not only in period of season [12]. Šiljković and Čuka (2004) concluded that the island's population has an urgent need for quality ship connection throughout the whole year because this is the only way to satisfy their living needs so the modernization of fleet and the system of the coastal liner maritime transport system is necessary [13]. The quality of the system depends on the optimum ship. Choosing a ship is a very complex process. Kovačić and Mrvica (2017) concluded with the research that the MCA method can be used to select the optimal ship [14]. All of the above is essential for the development of the island, but the importance of political activities at all levels cannot be overlooked, bearing in mind the character of the island, which Priano et al. (2016) point out [15].

\section{IMPORTANCE OF TRAFFIC CONNECTIVITY BETWEEN CROATIAN ISLANDS AND THE MAINLAND / Važnost prometne povezanosti među hrvatskima otocima i kopnom}

Croatian coast with its islands belongs to one of the most indented coastlines in the world and it makes the second largest Mediterranean archipelago comprising almost all islands of the eastern and central part coasts of the Adriatic. There are 1,246 islands, islets and reefs which make up $5.75 \%$ surface of Croatian mainland, but because of its pronounced indented coast, they belong to the coastline more than the mainland, or $69.5 \%$ of the total coastline [16].

The sea, numerous islands, islets and reefs are significant natural wealths with numerous advantages. Besides the benefits, there are also many limiting factors that cause a number of problems. With planning management, pre-quality analysis of the situation and limiting factors, islands can go through sustainable development and finally become a special and attractive place of investment and life in general.

For island population's lives, the most important is the connection to the mainland because without frequent and quality traffic connections there is no life on islands. It also tells to that fact that a significant increase in the number of inhabitants 
has been noticed on islands connected to the mainland by a bridge. On islands that are connected to the mainland by bridge, such as Krk, Pag, Vir, Murter and Čiovo, according to the last census population live 42,245 inhabitants, which is an increase of $10.3 \%$ compared to the previous census from 2001 [6]. Those islands that are connected to the mainland by bridge or are connected to the mainland by frequent and regular ship connections are also the most developed. A constant and firm connection to the mainland is a great development advantage, but in situations where this is not achievable, it is necessary to encourage the best ship connectivity. The importance of connecting the islands to the mainland is visible from Graph 1 where the steady growth of passengers and vehicles in coastal line transport of Croatia is visible and the number of passengers transported annually exceeds the number of 13 million.

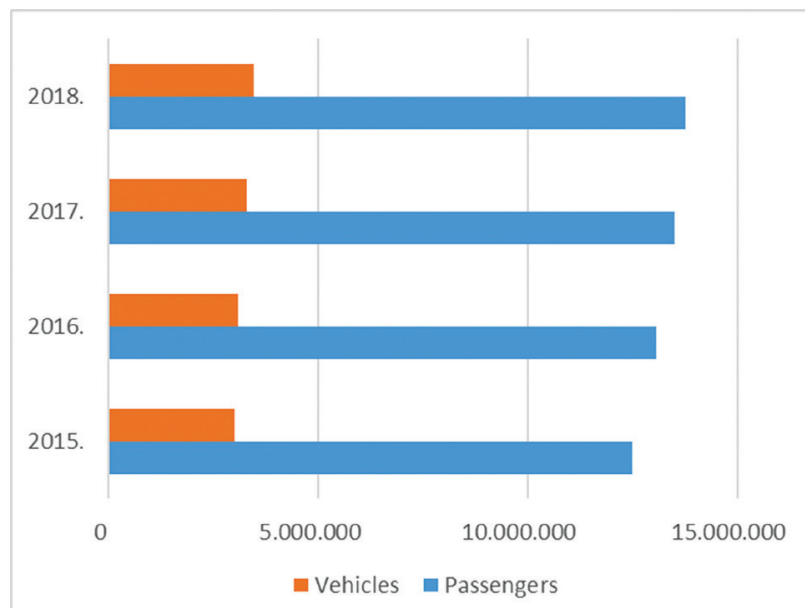

Source: Prepared by the authors according Agency for coastal maritime traffic Graph 1 The movement of the number of passengers and vehicles transported in the coastal line of maritime transport in Croatia for the period from 2015 to 2018

Graf 1. Gibanje broja putnika i vozila koji su prevezeni obalnom linijom pomorskoga prometa u Hrvatskoj za razdoblje od 2015. do 2018.

Transport service arising from the relocation of people and goods is one of the most important characteristics of transport. Larger islands that are closer to the coast are favorably solving their traffic problems while there are still small islands which needs for high-quality traffic connections are not being met. Croatia has a number of legal frameworks aimed at developing islands and preserving life on them and the their sustainable development implies a realisation of general objectives such as stable economic development of islands, fair distribution of social opportunities for all islanders, protection of islands' environment and increasing resilience to climate change [17]. In order to achieve best conditions for life and development of islands or to reach the previously set goals, establishment of a public transport system is necessary. Developed transport system facilitates and encourages mobility of people and goods and, by reducing transport isolation, enables productivity growth and creates assumptions for a balanced regional development [18], and the State and the public sector in 2017 invested in the development of islands almost 1.7 billion kunas, and the State allocated $381 \mathrm{mil}$ HRK in the name of support for the maintenance of state lines in the system of coastal line maritime transport [19]. On a better connection between islands and the mainland must be worked on systematically and continuously, because that way it directly affected the quality of life of islanders which in the long-term also affects the demographic image of our islands. If island habitants do not have the certainty to easily reach the mainland on all occasions, their life looses on the standard and they have fewer motives for staying on the island.

The island and its population needs a direct connection to the mainland because although life on the island has many advantages, islanders have to go ashore to compensate for the shortcomings of the life on the island such as the inability of employment and education, inadequate health care, lack of social and cultural content and others. This indicates the need for active implementation of maritime and transport policy in order to ensure the sustainable development of maritime and transport, i.e. sustainable development of islands and life on them, and consequently, the satisfaction of life needs of the island population. An efficient transport system is a prerequisite for economic development and it also has an active role in shaping the space and lives of people [20].

Croatia is not the exception to this issue. This is a problem of all maritime countries with indented coastline. Of course, as the indented coastline index is bigger, this problem is more pronounced and requires greater engagement from all participants, but foremost from the State. Investing in all forms of maritime-passenger transport and associated infrastructure does not only favour island development but also actively affects a better positioning of Croatia in Europe and in the world. Croatia's positioning is also manifested through tourism, and tourism and the sea are in close connection having a significant influence on the creation of the need for connectivity between islands and the mainland as well as for the development of ports and terminals. An efficient combination of these three factors leads to growth and economy development.

It is clear that the connection between islands and the mainland is of utmost importance and has a much wider effect than the question of islands, but with islands and islanders this question begins and ends, because better connectivity creates conditions for islands' economic development and better conditions of life for islanders, which contributes to the economy at the level of the whole country.

\section{ISLANDS' POPULATION / Populacija otokâ}

According to the last census from 2011, the proportion of people living on islands in the entire population of the Republic of Croatia is $2.92 \%$ or 124,955 people living on islands as permanent inhabitants. Compared to the previous 2001 census, when $2.8 \%$ of the people were listed as living on islands in relation to the total population, a relative increase in the island population is noticeable.

The islands are territorially encompassing seven counties, with six inhabited islands. Table 1 shows the division between the island population according to respective counties [6].

The analysis of the presented data in Table 1 concludes that the largest proportion of the island population is characterized by Dubrovnik-Neretva County and the smallest Šibenik-Knin county. Croatia's inhabited Adriatic islands are classified into four island groups:

a) Kvarner islands: Krk, Cres, Lošinj and Rab and a group of smaller islands

b) North Dalmatian islands: This group has entered the island of Pag, and all 
Table 1 Division between islands' population according to counties

Tablica 1. Podjela među otočnom populacijom prema županijama

\begin{tabular}{|c|c|c|c|}
\hline \multirow[b]{2}{*}{ County } & \multicolumn{2}{|c|}{ Population } & \multirow{2}{*}{ Share of the islands' population } \\
\hline & Total & Islands & \\
\hline Primorje-Gorski Kotar & 296.195 & 39.706 & $13,41 \%$ \\
\hline Lika-Senj & 50.927 & 3.663 & $7,19 \%$ \\
\hline Zadar & 170.017 & 20.952 & $12,32 \%$ \\
\hline Šibenik-Knin & 109.375 & 6.063 & $5,54 \%$ \\
\hline Split-Dalmatia & 454.798 & 36.338 & $7,99 \%$ \\
\hline Dubrovnik-Neretva & 122.568 & 18.233 & $14,88 \%$ \\
\hline Total & 4.284 .889 & 124.955 & $2,92 \%$ \\
\hline
\end{tabular}

Source: Elaboration of the authors from data obtained from the Croatian Bureau of Statistics

c) Islands from Silba to Krapanj

d) Central Dalmatian islands: from Drvenik Mali to Hvar and Vis

e) South Dalmatian islands: from Korčula and Lastovo to Koločep.

Although islands are usually characterized by isolation because the sea is separating them from the mainland and other islands, in the past they were doors of civilization and were not facing the modern problem of depopulation. The largest number of islanders was recorded in 1921, after which, until 1991, islands record a decline in population. Only the last two census figures from 2001 and 2011 show positive trends, which is confirmed by Graph 2 that shows the population trends in the said period on 15 most populated islands.

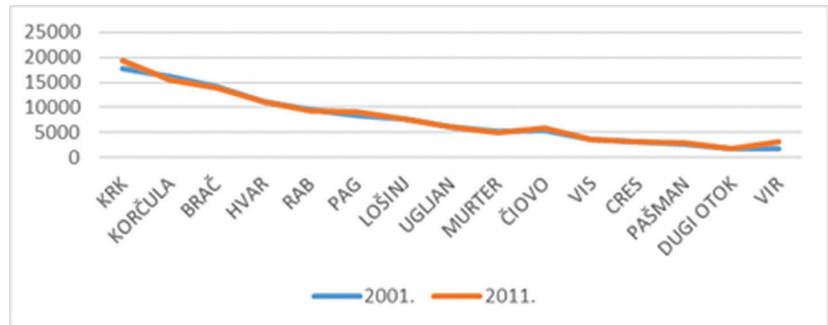

Source: Created by authors according Croatian Bureau of Statistics Graph 2 Population trends in 15 most populated islands in 2001 and 2011

Graf 2. Kretanje populacije na 15 najnaseljenijih otokâ u godinama 2001.i 2011.
Analyzing the data shown in Graph 2, it is concluded that it is not about large scale positive changes, but after a long time, an upward trend has been observed in the number of island population.

If a historical movement of population on the islands is being observed, different changes are noticed in different periods depending on number of factors that are presented in Table 2. A significant milestone was observed after II. World War when islands' population in coastal-island municipalities decreased by $47 \%$, and the largest decline of the islands' population of coastalisland municipalities was recorded between the list from 1971 and 1981 [8]. The table shows that the population of the Republic of Croatia increased continuously from the Second World War to the 1991, while the population on the islands decreased during the same period. Since 1991, it can be noticed the reverse process. There has been a positive trend of population growth on the islands, while the population at the level of the Republic of Croatia has been decreased. The table also shows that the share of the island population in the total population has decreased by $2.09 \%$ in the last hundred years (period 1910 - 2011).

However, islands and island groups differ in geographical, socio-economic and demographic characteristics. In particular, "bridge" islands are being highlighted for more favourable demographic trends and better economic development, while small islands are exposed to intensive depopulation and are in the process of transforming from permanently

Table 2 Population of Croatia's islands and total population of Croatia from 1857 to 2011 (without Pelješac) Tablica 2. Otočna populacija Hrvatske i ukupna populacija Hrvatske od 1857. do 2011. godine (osim Pelješca)

\begin{tabular}{|c|c|c|c|c|c|}
\hline List year & Population of Croatia's islands & $\begin{array}{l}\text { Index } \\
1857=100\end{array}$ & Population of Croatia & Index $1857=100$ & $\begin{array}{c}\text { Population of islands on the } \\
\text { total population (\%) }\end{array}$ \\
\hline 1857 & 117.481 & 100 & 2.181 .499 & 100 & $5,39 \%$ \\
\hline 1900 & 166.891 & 142 & 3.161 .456 & 145 & $5,28 \%$ \\
\hline 1910 & 173.263 & 147 & 3.460 .584 & 159 & $5,01 \%$ \\
\hline 1921 & 173.503 & 148 & 3.443 .375 & 158 & $5,04 \%$ \\
\hline 1931 & 165.624 & 141 & 3.430 .270 & 157 & $4,83 \%$ \\
\hline 1948 & 151.835 & 129 & 3.779 .858 & 173 & $4,02 \%$ \\
\hline 1953 & 150.073 & 128 & 3.936 .022 & 180 & $3,81 \%$ \\
\hline 1961 & 139.798 & 119 & 4.159 .696 & 191 & $3,36 \%$ \\
\hline 1971 & 127.598 & 109 & 4.426 .221 & 203 & $2,88 \%$ \\
\hline 1981 & 114.803 & 98 & 4.601 .469 & 211 & $2,49 \%$ \\
\hline 1991 & 110.953 & 94 & 4.784 .265 & 219 & $2,32 \%$ \\
\hline 2001 & 124.870 & 106 & 4.437 .460 & 203 & $2,81 \%$ \\
\hline 2011 & 125.082 & 106 & 4.284 .889 & 196 & $2,92 \%$ \\
\hline
\end{tabular}

Source: Created by the authors according Starc, N., 2016, 'Ka održivom razvoju otoka', Otoci i njihovi potencijali, Hrvatska akedemija znanosti i umjetnosti, Zagreb, p. 249-258, https://bib.irb.hr/prikazi-rad?rad=833675 (accessed 18 January 2019) 
Table 3 Movement of number and proportion of islands' inhabitants from 1981 to 2011 Tablica 3. Gibanje i udio otočnoga stanovništva od 1981. do 2011. godine

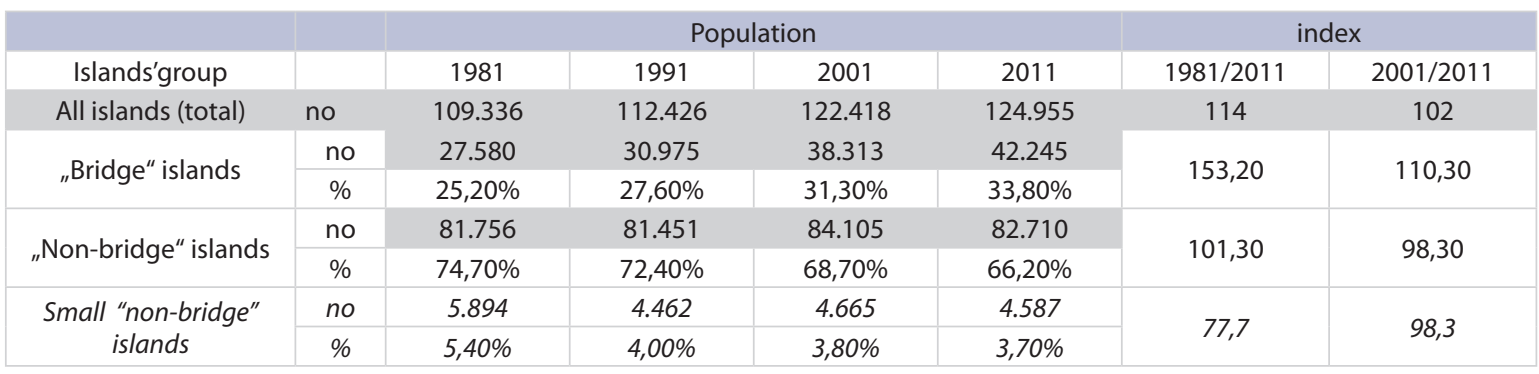

Source: Created by the authors according Lajić., I., Mišetić., R.,2013, 'Demografske promjene na hrvatskim otocima na početku 21. Stoljeća', Migracijske i etniĉke teme, Vol. 29, No. 2,pp.169-199

inhabited to occasionally populated areas [21]. Table 3 shows the positive movement of the population on "bridge" islands and the negative movement on "non-bridge" islands and especially small "non bridge” islands. „Bridge” islands in 2011 had a significant increase in population by $53.2 \%$ compared to 1981 or $10.3 \%$ compared to 2001 , "non-bridge" islands recorded in 2011 growth of 1.3\% compared to 1981, and a decline compared to 2001 while small islands recorded a steady decline in the number of inhabitants. On small islands there is a particular problem of lack of economic development which is a consequence of poor transport connectivity, as there are still those islands amongst Croatian small islands which needs for quality transport connections are partially satisfied or were not satisfied at all, which contributed to their depopulation.

It is clear that islands have been facing constant depopulation and migrations for a long time, but islands are also facing a very low birth rate. On all inhabited islands, dying is an incomparably more intense phenomenon compared to the islands' births resulting in birth rate being very low. An alarming phenomenon is also the increasingly significant reduction of young population on islands, and the increase of mature and old age groups, so that average age from total island population was recorded to be growing in the period from 2001 to 2011 ranging from 1.8 to 3.2 years [2].

This trend of changes in the age composition of island population restricts economic development and social activities and does not create a prerequisite for a more favourable movement of birth rates. The decline in birth rates and the increase of elderly population are phenomena that negatively affect demographic image and islands' economic development which ultimately undermines the sustainability of them.

This trend of changes in the age composition of island population restricts economic development and social activities and does not create a prerequisite for a more favourable movement of birth rates. The decline in birth rates and the increase of elderly population are phenomena that negatively affect demographic image and islands' economic development which ultimately undermines the sustainability of them.

\section{RELATION BETWEEN THE NUMBER OF ISLAND INHABITANTS AND SHIP LINES / Odnos broja otočnoga stanovništva naspram brodskih linija}

In all acts of The Republic of Croatia, from National Program of island development to the Act on islands, active role of the State, county administration and the local government on islands development is emphasized which implies the encouragement of traffic connectivity between islands and the mainland. The State has to appear actively on islands that require revitalization, as a special entrepreneur, who from the point of view of development of the whole island, invests in infrastructure and supra structure, calls and directs other entrepreneurs to sustainable development and prevents unsustainable investments [22]. This implies that the State should encourage the introduction of every single ship line linking the island to the mainland as this reduces the limiting factor of development and ensures a better standard of life for islanders. If islanders do not have conditions for life on islands, islands will become uninhabited and thus natural resources will be dead.

More recently, there have been positive changes and more attention has been paid to the preservation and improvement of life on the islands. Analyzing this issue, it has been highlighted a relative increase of island population between the last two census groups (2001 and 2011), but also the steps in connecting the island with the mainland or increasing the number of lines in the coastal line maritime transport system. Table 4 contains a number and frequency of lines, sorted by category (ferry lines, ship (classic) lines and fast boat lines), in year 2001 and 2017. It has been noted that a number of state lines in the system have augmented by 23\%, since in 2001 there were 42 lines, and in 2017, 52 lines.

The table also shows the overall daytime lines frequency in winter and summer schedule. In 2001, 139 calls were made on a daily winter schedule, 220 in summer and aprox 58,000 runs a year. In 2017, 177 calls were made in winter schedule, 291 ticks in summer, which is almost 75,000 calls per year. It can be concluded that in the observed period, except for the increase in the number of lines, the traffic density per year increased by $29 \%$.

By developing the coastal line maritime transport, the aim is to stimulate the growth of island's space. Positive shifts in transport connection of 15 most populated islands in Croatia in 2017, in comparison with 2001 shows Graph 3, that the system is developing in order to sustain life on the islands. 
Table 4 Lines in coastal line of Croatia's maritime transport in 2001 and 2017

Tablica 4. Linije u obalnoj plovidbi pomorskoga transporta Republike Hrvatske u godinama 2001. i 2017.

\begin{tabular}{|c|c|c|c|c|c|}
\hline \multicolumn{3}{|c|}{2001.} & \multicolumn{3}{|c|}{2017.} \\
\hline nb. & Ferry lines & $\begin{array}{l}\text { Daily frequency } \\
\text { (winter-summer) }\end{array}$ & nb. & Ferry lines & $\begin{array}{l}\text { Daily frequency } \\
\text { (winter-summer) }\end{array}$ \\
\hline 1 & BIOGRAD - TKON & 11 & 1 & JABLANAC - MIŠNJAK & $13-23$ \\
\hline 2 & BRBINJ - ZADAR & $2-3$ & 2 & BIOGRAD - TKON & 10-13 \\
\hline 3 & BRESTOVA - POROZINA & $15-19$ & 3 & BRBINJ - ZADAR & $2-4$ \\
\hline 4 & OREBIĆ - DOMINČE & $10-14$ & 4 & BRESTOVA - POROZINA & $8-13$ \\
\hline 5 & DRVENIK - SUĆURAJ & 4-9 & 5 & DRVENIK - DOMINČE & terminated 2014. \\
\hline 6 & DRVENIK - TROGIR & $1-2$ & 6 & DRVENIK - SUĆURAJ & 6-11 \\
\hline 7 & JABLANAC - MIŠNJAK & $9-22$ & 7 & DRVENIK VELI - DRVENIK MALI - TROGIR - SPLIT & $3-4$ \\
\hline 8 & KORČULA - DRVENIK & $1-3$ & 8 & DUBROVNIK - SUĐURAĐ - LOPUD & $1-2$ \\
\hline 9 & LASTOVO - SPLIT & 1 & 9 & LASTOVO - VELA LUKA - SPLIT & $2-4$ \\
\hline 10 & LOPAR - BAŠKA & 5 & 10 & MAKARSKA - SUMARTIN & $3-5$ \\
\hline 11 & MAKARSKA - SUMARTIN & 3-5 & 11 & OREBIĆ - DOMINČE & 14-18 \\
\hline 12 & PLOČE - TRPANJ & $4-7$ & 12 & PLOČE - TRPANJ & 4-7 \\
\hline 13 & PRIZNA - ŽIGLJEN & $6-10$ & 13 & PRAPRATNO - SOBRA & $4-5$ \\
\hline 14 & $\begin{array}{l}\text { RIJEKA - ZADAR - SPLIT - STARI } \\
\text { GRAD - KORČULA - DUBROVNIK }\end{array}$ & $0-1$ & 14 & PRIZNA - ŽIGLJEN & $13-21$ \\
\hline 15 & SOBRA - DUBROVNIK & $0-2$ & 15 & $\begin{array}{l}\text { RIJEKA - SPLIT - STARI GRAD - KORČULA - } \\
\text { DUBROVNIK }\end{array}$ & $0-1$ \\
\hline 16 & SPLIT - ROGAČ & $0-2$ & 16 & SPLIT - STARI GRAD & $4-7$ \\
\hline 17 & SPLIT - STARI GRAD & $3-5$ & 17 & SPLIT - ROGAČ & $4-6$ \\
\hline 18 & SPLIT - SUPETAR & $7-13$ & 18 & SPLIT - SUPETAR & $9-14$ \\
\hline 19 & VALBISKA - MERAG & $9-13$ & 19 & ŠIBENIK - ZLARIN - OBONJAN - KAPRIJE - ŽIRJE & $1-3$ \\
\hline 20 & VIS - SPLIT & & 20 & VALBISKA - LOPAR & $2-4$ \\
\hline 21 & ZADAR - BRŠANJ & $1-2$ & 21 & VALBISKA - MERAG & $10-17$ \\
\hline 22 & ZADAR - PREKO & $13-15$ & 22 & VIS - SPLIT & $2-3$ \\
\hline \multirow[t]{4}{*}{23} & ZADAR - PREMUDA & 1 & 23 & ZADAR - BRŠANJ - RAVA & $0-2$ \\
\hline & & & 24 & $\begin{array}{l}\text { ZADAR - IST - OLIB - SILBA - PREMUDA - MALI } \\
\text { LOŠINJ }\end{array}$ & 1 \\
\hline & & & 25 & ZADAR - OŠLJAK - PREKO & 15-18 \\
\hline & & & 26 & $\begin{array}{l}\text { ZADAR - RIVANJ - SESTRUNJ - ZVERINAC - } \\
\text { MOLAT - IST }\end{array}$ & 1 \\
\hline $\mathrm{nb}$. & Ship (classic) lines & & nb. & Ship (classic) lines & \\
\hline 1 & RAVA -IŽ-ZADAR & $0-1$ & 1 & BRODARICA - KRAPANJ & 4-17 \\
\hline 2 & KORČULA - OREBIĆ & $10-14$ & 2 & KOMIŽA - BIŠEVO & $0-1$ \\
\hline 3 & ŠIPAN - DUBROVNIK & $1-3$ & 3 & OREBIĆ - KORČULA & 14-18 \\
\hline 4 & UNIJE - MALI LOŠINJ & 2 & 4 & RAVA - IŽ - ZADAR & 1 \\
\hline 5 & VODICE - ŠIBENIK & $2-5$ & 5 & ZADAR - SALI - ZAGLAV & $1-3$ \\
\hline 6 & VRGADA - PAKOŠTANE - BIOGRAD & $4-5$ & 6 & ŠIPAN - LOPUN - KOLOČEP - DUBROVNIK & $2-4$ \\
\hline 7 & ZAGLAV - ZADAR & $1-3$ & 7 & TROGIR - SLATINE - SPLIT & $1-7$ \\
\hline \multirow[t]{3}{*}{8} & ŽIRJE - ŠIBENIK & $1-2$ & 8 & UNIJE - SRAKANE - SUSAK - MALI LOŠINJ & 1 \\
\hline & & & 9 & VODICE - PRVIĆ - ZLAARIN - ŚIBENIK & $3-5$ \\
\hline & & & 10 & VRGADA - PAKOŠTANE - BIOGRD & 1 \\
\hline nb. & Fast boat lines & & nb. & Fast boat lines & \\
\hline 1 & IST - MOLAT- ZADAR & $0-1$ & 1 & $\begin{array}{l}\text { DUBROVNIK - ŠIPANSKA LUKA - SOBRA - } \\
\text { POLAČE- KORČULA - LASTOVO }\end{array}$ & $1-2$ \\
\hline 2 & KORČULA - HVAR - SPLIT & $1-2$ & 2 & IST - MOLAT - ZADAR & $1-3$ \\
\hline 3 & MALI LOŠINJ - RIJEKA & 1 & 3 & JELSA - BOL - SPLIT & 1 \\
\hline 4 & MLJET - ELAFITI - DUBROVNIK & 1 & 4 & KORČULA - PRIGRADICA - HVAR - SPLIT & 1 \\
\hline 5 & OLIB - PREMUDA - SILBA - ZADAR & 1 & 5 & LASTOVO - VELA LUKA - HVAR - SPLIT & $1-4$ \\
\hline 6 & ROGAČ - SPLIT & $3-5$ & 6 & $\begin{array}{l}\text { MALI LOSINJ - ILOVIK - SUSAK - UNIJE - } \\
\text { MARTINŠĆICA - CRES - RIJEKA }\end{array}$ & 1 \\
\hline 7 & SALI - ZADAR & $1-2$ & 7 & NOVALJA - RAB - RIJEKA & 1 \\
\hline 8 & SPLIT - BOL - JELSA & 1 & 8 & OLIB- SILBA - PREMUDA - ZADAR & 1 \\
\hline 9 & UBLI - VELA LUKA - HVAR - SPLIT & 1 & 9 & PULA - UNIJE - MALI LOŠINJ - ILOVIK - ZADAR & $0-1$ \\
\hline 10 & VIS - SPLIT & $1-3$ & 10 & SPLIT - MILNA - HVAR & terminated 2014. \\
\hline \multirow[t]{6}{*}{11} & ŽIRJE - KAPRIJE - ŠIBENIK & $1-2$ & 11 & SPLIT - ROGAĆ - STOMORSKA & 2 \\
\hline & & & 12 & VIS - HVAR - SPLIT & 1 \\
\hline & & & 13 & ZADAR - SALI - ZAGLAV & 3 \\
\hline & & & 14 & ZADRA - IZZ - RAVA & 1 \\
\hline & & & 15 & $\begin{array}{l}\text { ZVERINAC - BOŻAVA - SESTRUNJ - RIVANJ - } \\
\text { ZADAR }\end{array}$ & 1 \\
\hline & & & 16 & ŽIRJE - KAPRIJE - ŠIBENIK & $1-3$ \\
\hline
\end{tabular}

Source: Creted by the authors according to the Ministry of the Sea, Transport and Infrastructure 


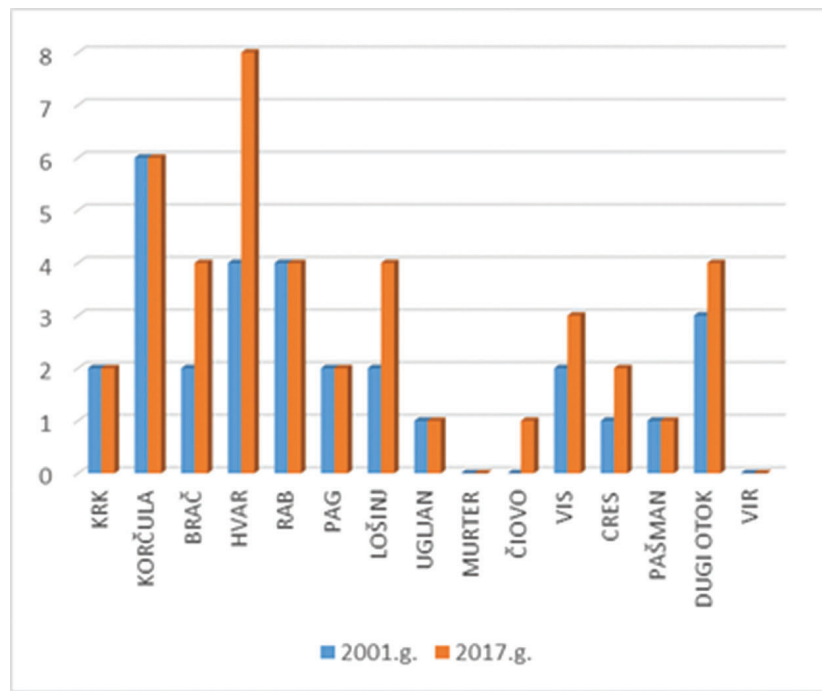

Source: Created by the authors according Croatian Bureau of Statistics and Ministry of the Sea, Transport and Infrastructure

Graph 3 The ratio of number of lines of 15 most populated islands in 2001 and 2017

Graf 3. Odnos broja linija 15 najnaseljenijih otoka u godinama 2001. i 2017.

While coastal line traffic shows slight growth, no significant increase in the number of inhabitants has been observed on "non-bridge" islands. Analyzing data from Table 4 and Table 5 concludes that there is no direct correlation between the number of inhabitants on islands and the number of ship lines connecting islands with the mainland. Population growth is visible on islands connected to the mainland by a solid berth or a bridge. This form of connectivity facilitates all the functions on islands due to the availability of necessary facilities and it equates the quality of life on mainland with islands, by which islands become an interesting space for life, since the limiting factor of traffic connectivity is reduced to the smallest possible level. Where a bridge is not an available solution, what should be encouraged is a more frequent connection between islands and mainland because a better and more frequent connection between them effects quality of life of islanders, creating prerequisites for population, especially members of younger population for returning and staying on the island. The basis for development of life on islands is ensured by existence and therefore it is necessary to develop all economic activities which can survive on islands and thus bring closer islands and other markets and economic subjects because this is a key element for a more successful inclusion of islands in the Croatian economic system and the increase of populated island units.

\section{ISLAND'S ECONOMY / Otočno gospodarstvo}

The island's economy is reflected mostly in branches of tourism, agriculture, fishing, stone farming and shipbuilding. It has always been simple and poor which confirms the fact that even in the best years it did not exceed 5\%-7\% share in the total economy of The Republic of Croatia. The economy on the islands, as well as economy on the mainland is subject to the changes in the surrounding, but it is a more sensitive category with more pronounced oscillations. Today attention to islands, in economic terms, attracts tourism the most due to its profitability. Islands are very interesting to various investors for the development of tourism because of its natural beauties and still present originality, but it is necessary that environmental preservation and socially responsible construction are ahead of profit and money.

The indented coastline, clean sea, climate, preserved environment and natural beauty with historical and cultural heritage offer numerous possibilities for further development of tourism. These advantages, along with maritime characteristics of our coastline attract many yachtsmen, so Croatian islands are experiencing bigger growth in nautical tourism segment, with a clear need for investment in ports and infrastructure. The needs and desires of tourists change year after year and such challenges need a quick reaction to compete in the right way

Table 5 Relation between number of ship lines and the population on 15 most populated islands Tablica 5. Odnos broja brodskih linija i populacije na 15 najnaseljenijih otoka

\begin{tabular}{|c|c|c|c|c|c|c|c|c|c|}
\hline \multirow[b]{2}{*}{ ISLAND } & 2001. & 2017. & & 2001. & 2017. & & 2001. & 2017. & \multirow[b]{2}{*}{ NOTICE } \\
\hline & POP. & POP. & $\%$ & NB OF LINES & NB OF LINES & $\%$ & $\begin{array}{c}\text { NB OF } \\
\text { INHABITANTS } \\
\text { PER LINE }\end{array}$ & $\begin{array}{c}\text { NB OF } \\
\text { INHABITANTS } \\
\text { PER LINE }\end{array}$ & \\
\hline KRK & 17,860 & 19,338 & 108,28 & 2 & 2 & 100,00 & 8,930 & 9,669 & bridge \\
\hline KORČULA & 16,182 & 15,522 & 95,92 & 6 & 6 & 100,00 & 2,697 & 2,587 & \\
\hline BRAČ & 14,031 & 13,956 & 99,47 & 2 & 4 & 200,00 & 7,016 & 3,489 & \\
\hline HVAR & 11,103 & 11,077 & 99,77 & 4 & 8 & 200,00 & 2,776 & 1,385 & \\
\hline RAB & 9,480 & 9,328 & 98,40 & 4 & 4 & 100,00 & 2,370 & 2,332 & \\
\hline PAG & 8,398 & 9,059 & 107,87 & 2 & 2 & 100,00 & 4,199 & 4,530 & bridge \\
\hline LOŠINJ & 7,771 & 7,587 & 97,63 & 2 & 4 & 200,00 & 3,886 & 1,897 & $\begin{array}{l}\text { bridge-connection } \\
\text { with Cres }\end{array}$ \\
\hline UGLJAN & 6,164 & 6,049 & 98,13 & 1 & 1 & 100,00 & 6,164 & 6,049 & $\begin{array}{l}\text { bridge-connection } \\
\text { with Pašman }\end{array}$ \\
\hline MURTER & 5,060 & 4,895 & 96,74 & & & & & & bridge \\
\hline ČIOVO & 5,387 & 5,908 & 109,67 & & 1 & & & 5,908 & bridge \\
\hline VIS & 3,617 & 3,445 & 95,24 & 2 & 3 & 150,00 & 1,809 & 1,148 & \\
\hline CRES & 3,184 & 3,079 & 96,70 & 1 & 2 & 200,00 & 3,184 & 1,540 & $\begin{array}{l}\text { bridge-connection } \\
\text { with Lošinj }\end{array}$ \\
\hline PAŠMAN & 2,711 & 2,845 & 104,94 & 1 & 1 & 100,00 & 2,711 & 2,845 & $\begin{array}{l}\text { bridge - connection } \\
\text { with Ugljan }\end{array}$ \\
\hline DUGI OTOK & 1,772 & 1,655 & 93,40 & 3 & 4 & 133,33 & 591 & 414 & \\
\hline VIR & 1,608 & 3,000 & 186,57 & & & & & & bridge \\
\hline
\end{tabular}

Source: Created by the authors according Croatian Bureau of Statistics and Ministry of the Sea, Transport and Infrastructure 
on the market, but also to remain an attractive destination. Changes are necessary because tourists are becoming more demanding and the sea and the sun are often not enough.

However, the largest capitals of the island, importance and originality of islands must not be endangared. The goal is a long-term tourism development and islands that can only be achieved through implementation of thoughtfully created development policy in all domains essential for islands. Significance of tourism is visible through example listed in Graph 4 where we see on three Dalmatian islands a significant increase in number of tourists in 2017 compared to 2011. The situation is similar on other islands of Croatia, therefore it can be said that tourism is a basic source of income for islands and as such is an important factor of their economic development which can only ensure their survival because it directly affects the decrease in general occurrence of depopulation.

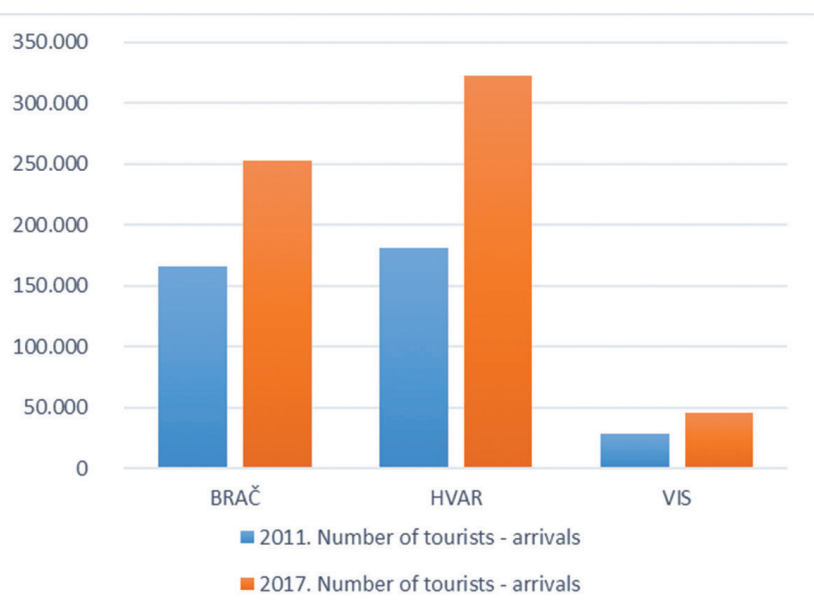

Source: Created by the authors according Croatian Bureau of Statistics Graph 4 Movement of number of tourists on 3 Dalmatian islands in 2011 and 2017

Graf 4. Stanje broja turista na 3 dalmatinska otoka u godinama 2011. i 2017.

The industry branch that has been significantly reduced and overruled by tourism today is agriculture but is nonetheless still present and essential for islands and their population. Agriculture was once a basic economic branch. In the structure of agriculture, viticulture and olive growing are the most present branches. Although there are less vineyards on islands, $10-15 \%$ of the total wine production in Croatia is a product of islands' production, which are very high quality and demanded wines. Olive growing is no less important for islands and this branch with full right has recently been given more and more attention because of the quality of products that result in good market demand has been recognised. More than half of the total amount of olives in Croatia are being cultivated on islands and there are all prerequisites for increasing the production of olive oil in which islands can play a major role in. Agricultural resources on islands can certainly be better exploited with adequate measures and incentives.

One of the oldest ways of exploiting the sea is fishing and islands are certainly not lagging behind in this regard in terms of their position. The low share of fishing in Croatian GDP does not mean at the same time unimportance of this activity, which includes fishing, mariculture, fish processing and sale of fish and fish products, because fishing has always played a big role in the life of islanders. Today, this activity means realization of income, employment of islanders, lifestyles, local identity and tourist attraction, although a reduction in the use of production capacities in the fishery has been observed, due to transitional problems, loss of former market, customs restrictions and the failure to comply with the EU market standards. Catches and cultivation (production) of sea fish and other sea organisms in the Republic of Croatia were smaller in 2017 than in the previous year by $2.0 \%$ [23]. It is clear that there are needs, but also opportunities for development of fisheries on islands. Fisheries have an economic, environmental and social role, and one of the main objectives is to ensure the sustainable management of natural resources in fisheries and the protection of natural wealth, so measures of controlled fish catch and protection of endangered species must be carried out [24].

In addition to the aforementioned economic activities represented on Croatian islands, shipbuilding must not be ignored as a very important factor in the island industry because it connects many other economic activities and in that way directly influences development of islands and creation of prerequisites for the life on islands. It is evident that islands have many advantages that can be adequately exploited in order to develop the economy without compromising the character of the island. Islands also face a number of limiting factors in their economy development which should be minimised, if they are subject to change, and one of the most important such limiting factors is the traffic cut from the mainland. Development of island's traffic connection with the mainland directly affects all the mentioned economic branches because traffic is the initiator of all development flows of the island. The most pronounced is the interdependence of tourism and transport connections because that way it is only possible to expect revitalization of Croatian tourism and it has been proved that tourism is the most pronounced base for economic development of Croatian islands. Without quality traffic connectivity 4,322 companies on islands would not be able to function nor could 21,542 employees receive benefits that are necessary so that every single household can survive and that islanders could stay on islands. Therefore, without growth and investment in the economy it is not realistic to expect a better demographic image of islands and the prerequisite for growth of the economy is the development of transport connectivity.

\section{CONCLUSION / Zaključak}

The characteristic of Croatian coast is in the indented and numerous islands, islets and reefs, which in addition to positive qualification obliges the protection of these natural resources and their best use. Islands are by definition isolated spaces from the mainland, but also parts of larger island and island-coastal groups. They struggle with a number of problems in order to survive, and one of the biggest problems is the depopulation that has an unstoppable course ever since 1921. Today there are certain changes in the number of island population, but not in such a recognizable extent that these figures would still not be worrying. It is essential that all State levels approach this problem actively and thoughtfully because otherwise the islands will dominate the uninhabited area which leads to their neglect and dying. The extremely low birth rate and the 
predominance of the older population in the structure of the island population indicates poor future economic and social activity of the island. The aim is to preserve islands and lives on them, so it is essential to implement a number of economic and political measures to achieve the same. Each island has its own peculiarities, but islands' problems are the same, and as a basic highlight is the problem of connection with the mainland. It has been proven that an effective solution to this problem diminishes all other problems which confirms the fact that the most developed islands are those that are connected to the mainland by a bridge. Improved traffic connections to the mainland will not immediately improve the demographic image because they are not closely correlated, but will positively effect changes in socio-economic circumstances which are the basic prerequisites for stabilizing demographic and development tendencies. Islands will survive if there is a life on them and this is possible if certain standards of quality of life are met. Realistic viewing of the situation, long-term planning and finding the best quality solutions in reducing the influence of limiting factors such as the level of traffic connectivity of the island with the mainland, or the optimal exploitation of natural resources while preserving the character and originality of the island, ensures the long-term development of the island and their survival.

\section{REFERENCES / Literatura}

[1] Duplančić-Leder, T., Ujević, T., Čala, M., Viđak, I., 2000., 'Categorization and number of islands in the Republic of Croatia', Periodicum Biologorum, vol.102, Suppl 1, p. 281-284

[2] Lajić, l., Mišetić, R., 2013., 'Demografske promjene na hrvatskim otocima na početku 21. stoljeća', Migracijske i etničke teme, vol. 29, no. 2, p. 169-199. https://doi.org/10.11567/met.29.2.3

[3] Baldacchino, G., 2019., 'How far can one go? How distance matters in island development', Island Studies Journal, Institute of Island Studies, University of Prince Edward Island, Canada. https://doi.org/10.24043/isj.70

[4] Marinković, V., 2016., 'Sociogeographical elements and determinants of croatian islands classification', Geoadria, Vol.21, No.1, pp. 143-166

[5] Magaš, D., 1996., 'Hrvatski otoci - glavne geografske i geopolitičke značajke, Geoadria, Vol.1, No.1, pp. 5-16. https://doi.org/10.15291/radovipov.2220
[6] Magaš, D., 2011., 'Prirodno geografska osnova - potencijal razvoja otoka Ista i Škarde', Geoadria, Vol.16, No.2, pp. 283-286. https://doi.org/10.15291/ geoadria.101

[7] Zlatar, J., 2010., 'Odrednice turističke djelatnosti u smjeru održivog razvoja primjer mjesta Povlja na otoku Braču', Sociologija i prostor, Vol.48, No.2(187), pp. 247-272

[8] Jovanović, J., Galić, J., Mackelworth, P., 2010., 'The Impact of Closing Fish Processing Plants onto the Process of Depopulation of Croatian Islands', Naše more, Vol.57, No.3-4, pp. 153-163

[9] Yang, J., Ge, Y., Ge, Q. , Xi, J., Li, X., 2016., ' Determinants of island tourism development: The example of Dachangshan Island', Tourism Management, Vol.55, pp. 261-271. https://doi.org/10.1016/j.tourman.2016.03.001

[10] Vidučić, V., 2007., 'Održivi razvoj otočnog turizma republike hrvatske', Naše more, Vol.54, No.1-2, pp. 42-48

[11] Delibašić, T., Vidučić, V., 2003.,'Međuovisnost putničkoga morskog brodarstva i turizma u Hrvatskoj', Zbornik radova, Sveučilište Rijeka, Ekonomski fakultet, god.21, Sv.2, pp. 77-92

[12] Mrvica, A., Jugović, A., Kovačić, M., 2015., 'The role and applicability of multi-criteria procedures in the function of defining the model for connecting the mainland and islands and islands in between', Pomorstvo, Vol.29, No.2, pp. 156-164

[13] Šiljković, Ž., Čuka, A., 2004., 'Traffic connection and reasons for commuting from Zadar islands to Zadar', Geoadria, Vol.9, No.2, pp. 211-222

[14] Kovačić, M., Mrvica, A., 2017., 'Selecting the Size and Type of a Vessel for the Purpose of Maritime Connection of Mainland and Islands and Between the Islands in Croatia', Proceedings of XLIV Symposium on Operational Research, Beograd, pp. 771-777

[15] Priano, F. H., Armas, R. L., Guerra, C. F., 2016., 'A Model for the Smart Development of Island Territories', Proceedings of the 17th International Digital Government Research Conference on Digital Government Research, pp. 465-474. https://doi.org/10.1145/2912160.2912187

[16] Starc, N., 2016., 'Ka održivom razvoju otoka', Otoci i njihovi potencijali, Hrvatska akedemija znanosti i umjetnosti, Zagreb, pp. 249-258

[17] Zakon o otocima, Narodne novine 116/18

[18] Strateški plan Ministarstva mora, prometa i infrastrukture za razdoblje 2016. 2018., 2016., http://www.mppi.hr/UserDocsImages/MPPI\%202016-2018\%20 STRAT-PL\%20IZM-DOP\%204-4_16.pdf (accessed 03 February 2019)

[19] Izvješće o učincima provedbe Zakona o otocima 2017. g.

[20] Violić, A., Debelić, B., 2014.,'Uloga pomorske i prometne politike u funkciji održivog razvitka prometa i pomorstva', Pomorski zbornik, Vol.47-48. No.1., pp. 13-26

[21] Nakićen, J., Čuka, A., 2016., 'Demografski razvoj otoka Brača i sklonost otočana iseljavanju', Migracijske i etničke teme, Vol.32, No.3, pp. 336-339. https://doi. org/10.11567/met.32.3.2

[22] Nacionalni program razvitka otoka, 1997. http://www.mppi.hr/ userdocsimages/2007/NPRO-RH.pdf (accessed 26 January 2019) Državni zavod za statistiku RH, 2018., https://www.dzs.hr/Hrv_Eng/ publication/2018/01-04-01_01_2018.htm (accessed 03 February 2019)

[23] Zakon o morskom ribarstvu, Narodne novine 62/17, 130/17 